\title{
Utopias and "Normality": 1968 Revisited Fifty Years On
}

\author{
Jacques Rupnik
}

"Czechoslovakia in 1968 represented an important moment in human history; it did not represent an important international crisis."1 The verdict of two eminent British professors of international relations written instantly after the tanks of August put an end to the Czechoslovak experiment of "socialism with human face" was brutal and painfully accurate. The division of the continent was confirmed and a new version of east-west "détente," based on that understanding, could be launched. The significance of the Prague Spring cannot be measured only by its defeat, however. Its contribution should be understood in the interplay between its Czecho-Slovak and European dimensions. The August '68 invasion might not have provoked a "major international crisis," as the two professors stated, but it certainly was the year that shook Europe. Three aspects deserve to be mentioned in this respect. First, the Prague Spring revived the debate about Czech democratic exceptionalism in the context of (east) European socialism. Second, it was often interpreted as part of an international, generational revolt against the establishments, east and west. Third, it represented the most far-reaching reform of the system within the Soviet sphere and provided twenty years later a belated (and thus doomed) inspiration for Mikhail Gorbachev's botched attempt to save it, which indeed paved the way for 1989.

The Prague Spring was not what you read about in school textbooks that start with the election of Alexander Dubček as party leader on January 5, 1968 and conclude with the Soviet-led invasion of August 21. Rather, it should be understood as a process starting in the early 1960s, with converging pressures for economic reforms identified with the name Ota Sik; Slovak resentment of Prague centralism (hence Alexander Dubček and the federalization project); and the gradual emancipation of the cultural sphere from the stranglehold of ideological censorship, which accounts for the golden age of Czech cinema, theater, and literature with a significant and lasting impact throughout Europe. The culmination of the three-pronged process brought about political change, starting with the abolition of censorship and the separation of party and state. In other words, 1968 was not just a parlor game for reform-minded party bureaucrats. It was, in Václav Havel's words, "above all a civic renewal, a restoration of human dignity, the trust in the capacities and possibilities of citizens to change society."2

Post-1968 interpretations of the democratization process revived variations on the theme of Czech exceptionalism in east central Europe. The first could be summed up as the triumph of Czech and Slovak culture over the

1. Philip Windsor and Adam Roberts, Czechoslovakia, 1968: Reform, Repression, Resistance (New York, 1969).

2. Václav Havel, “La citoyenneté retrouvée,” Introduction to J. Rupnik and F. Fejtö, eds., Le printemps tchécoslovaque 1968 (Bruxelles, 1999), 12. 
communist structure. The emancipation of the cultural sphere from the constraints of censorship without being subjected to market pressures produced a powerful 60s cultural background to the political and societal changes associated with 1968. A related version of the argument concerns the enduring democratic character of Czech political culture. Authors like Archie Brown and Gordon Skilling in his monumental study of the Prague Spring have argued that the legacies of pre-war democracy, followed between 1945 and 1948 by a "democratic interlude," have left in society (even in large parts of the Communist Party membership) values, beliefs, and a political culture that were in conflict with the Stalinist regime and that eventually came to the surface in the 1960s and helped to bring about fundamental change that represented a break from Soviet-type communism. ${ }^{3}$ Hence, the problematic title of Skilling's book, The Interrupted Revolution. In contrast to the Hungarian revolution of 1956, and in order to avoid a similar outcome, the Prague reformers were eager to stress that they meant change within socialism. Yet abolishing censorship and separating party and state fostered a dynamic that challenged the fundamentals of the communist system.

One of the most interesting debates about the meaning of 1968 was expressed through the opposition of two leading Czech intellectuals, Milan Kundera and Václav Havel, which is worth re-reading half a century later, although not for a post-invasion assessment. ${ }^{4}$ Kundera's overstatement, inspired by the formidable peaceful civic resistance of August 1968, asserting that the reformist project could survive the invasion, was mercilessly dismissed by Havel as sheer delusion. It is the meaning of the Spring of 1968, however, which is worth revisiting. Following on H. Gordon Schauer's provocative nineteenth century question about what ultimately justifies the efforts put into producing a culture in the Czech language, Kundera makes a plea for the contribution of small nations to universal values, ideas, culture:
A small nation, if it has any meaning in the world, has to daily, constantly re-create itself. The moment it ceases to create values, it loses the justifica- tion for its existence and then perhaps actually ceases to exist, because it is fragile and vulnerable. The creation of values is connected with its very being. ${ }^{5}$

For Kundera the Prague Spring was of significance to Europe as a whole because, beyond eastern Stalinism and western capitalism, it tried to combine socialism with democracy. Not a mere remake of the "third way" or a blueprint for a radiant future, the Czechoslovak heresy was crushed but the far-reaching significance of the project for the future of the European Left remains.

3. Gordon H. Skilling, Czechoslovakia's Interrupted Revolution (Princeton, 1976); Archie Brown and Gordon Wightman, "Czechoslovakia: Revival and Retreat," in Archie Brown and Jack Gray, eds., Political Culture and Political Change in Communist States (New York, 1977), 159-96.

4. Milan Kundera, “Český úděl,” Literarni Listy 7-8, December 19, 1968, (“Czech Destiny”), trans. Tim West; Václav Havel, “Český úděl?” (“Czech Destiny”), Tvar, April 1969. The three articles (with Kundera's reply to Havel) reprinted in Literarni Noviny, December 27, 2007.

5. Milan Kundera, “Český úděl?,” 5. 
Havel's take, in contrast, was more sober and realistic, far from the "provincial messianism" he attributed to Kundera. Restoring basic freedoms was no doubt a great achievement, but the last time we had them was thirty years ago and indeed this is considered "normal" in most "civilized" countries. Therefore, 1968 was about liberal democratic normality, as opposed to the repressive "normalization" that followed:

... If we are going to imagine that a country has placed itself at the center of world history because it wishes to establish freedom of expressionsomething taken for granted in most of the civilized world-and to check the tyranny of its secret police, in all seriousness we shall become nothing more than self-complacent hacks, laughable in our provincial messianism! Freedom and the rule of law are the most basic preconditions for a normally and soundly functioning societal organism, and should any state attempt to reestablish them after years of their absence it is doing nothing historically momentous but simply trying to remove its own abnormality. ${ }^{6}$

For some thirty years it seemed that the verdict on Kundera's somewhat messianic vision vs Havel's lucid realism seemed fairly obvious to most Czechs. Yet today, half a century later, with communism long dead and western liberal-democratic "normalcy" in crisis, Kundera's plea for the "Czechoslovak possibility" in 1968 acquires perhaps a new resonance.

A second reading of the Prague Spring highlights its European dimension and calls us to interpret it through the prism of the rebellions that shook the political establishments throughout the continent in '68. There was May '68 in France, the Polish events of March '68, Berlin, Belgrade ...

The common denominator of these movements was the search for alternative models of society with contrasting, confusing, and often contradictory references to "socialism": from self-management in the workplace to the Christian-Marxist dialogue or to discussions about the impact of science and technology on the evolution of modern societies in both east and west. Moreover, there were not insignificant Czech contributions to all of the above. Karel Kosik's Marxist humanism (influenced by Jan Patocka's phenomenology) and a civilizational pessimism related precisely to the dehumanizing role of science and technology, or on the contrary, Radovan Richta's civilizational optimism based on the "scientific and technical revolution." The former proved incompatible with the "normalization" Gleichschaltung of the 1970s, while the latter's technocratic faith in the progress of sciences rather easily blended in. Both were among the most influential Czech thinkers of the late 1960s in Europe and both were thus part of what Jan Patocka had in mind in attempting to frame the Prague Spring reforms in a European context and calling for a dialogue between intellectuals east and west. Patocka's contribution was a piece entitled "Inteligence a opozice," based on a lecture given during the Spring of 1968

6. Václav Havel, “Český úděl?” at https://www.academia.edu/2503514/Czech_ Destiny_V\%C3\%A1clav_Havel_(last accessed September 20, 2018).

7. 1968 was the year Karel Kosik's Dialectic of the Concrete (Dialektika konkrétniho, 1966) and Radovan Richta's Civilization at the Crossroads (Civilizace na rozcesti, 1967) were translated in western Europe. 
in Germany, where he states that "the position of intellectuals in the East is better because 'they do not consider basic democratic rights as a mere means towards an end but an end in itself'." 8

This proved to be the main contrast between 1968 in Prague (or Warsaw) and Paris (or Berlin). To be sure, there is a whole aspect of 1968 that can be interpreted mainly in terms of generations. There is now even a term for this: "Youthquake," declared in 2017 as the "Word of the Year" by the experts at Oxford Dictionaries. It is defined as "significant cultural, political, or social change arising from the actions or influence of young people." 9 The interesting thing about the Prague Spring was that there was indeed youth participation, particularly the student movement as its radical wing, but its driving force was the previous generation, which experienced (supported or was at the receiving end of) state actions in 1945-48 and their aftermath. A.J. Liehm, the editor of Literarni listy in 1968, elaborated on this concept of political generations precisely in 1968 in the introduction to a splendid volume of his interviews with the leading intellectual figures of 1968 (from Ludvik Vaculik to Josef Skvorecky, and from Eduard Goldstücker to Václav Havel, to mention only a few), among the best guides to the culture politics of the Prague Spring. ${ }^{10}$ Many-by no means all-of those who had been twenty after the WWII and had backed the communist takeover in 1948 found themselves frustrated and disappointed with the revolution from above, and thus helped in the 1960s to bring about a revolution from below, which culminated in $1968 .{ }^{11}$

The generational aspect, as much as the political context, account for the contrasts and misunderstandings of 1968 between east and west, Prague and Paris. The driving force of the Prague Spring was the aspiration of freedom, whereas in Paris the moment of emancipation combined with the myth of revolution. Milan Kundera described the contrast as follows:

Paris May '68 was an explosion of revolutionary lyricism. The Prague Spring was the explosion of post-revolutionary skepticism ... May '68 was a radical uprising whereas what had, for many a long year, been leading towards the explosion of the Prague Spring was a popular revolt by moderates. ${ }^{12}$

8. Jan Patocka, Sebrané Spisy, vol. 12 (Prague, 2016), 241-43.

9. See https://en.oxforddictionaries.com/word-of-the-year/word-of-the-year-2017 (last accessed October 10, 2018).

10. Antonin J. Liehm, “Generace znamena v cestine singular i plural," Introduction to Generace (Praha, 1969 [banned before distribution] and 1990). The book was translated in several languages with a lengthy afterword by Jean-Paul Sartre, "The Socialism that Came in from the Cold," Introduction to Antonin J. Liehm, The Politics of Culture (New York, 1973).

11. Their radicalism in undoing what they had helped to bring about two decades earlier perplexed the non-communists and particularly those belonging to an in-between generational group: see the samizdat volume Zivot je vsude, Almanach roku 1956 (Praha, 2005), edited by Josef Hiršal and Jiři Kolář, with contributions of Skvorecky, Hrabal, Julis, Kolar, Hirsal, Zabrana, Kubena and a certain Václav Havel.

12. Milan Kundera, Preface to the French edition of Josef Skvorecky and Claudia Ancelot, Miracle en Bohème [Mirákl: Politická detektivka in original Czech] (Paris, 1978), x. 
While western radicals looked to the Third World (post-colonial guilt), European identity was part of Spring of 1968 in Prague. Again, in Kundera's words:

Paris in May '68 challenged the basis of what is called European culture and its traditional values. The Prague Spring was a passionate defense of the European cultural tradition in the widest and most tolerant sense of the term (a defense of Christianity just as much as of modern art-both rejected by those in power). We all struggled for the right to maintain that tradition that had been threatened by the anti-western messianism of Russian totalitarianism."13

The contrast and misunderstandings highlighted here, however, should not make us forget the intellectually and politically important convergence between the western 68ers who in the following decade abandoned Marxism and became anti-totalitarian liberals of different shades and the post-68 Czech dissidents around common issues and concerns: human rights, civil society, and overcoming the partition of Europe.

Finally, there is another dimension to the Spring of 1968 as the "supreme stage" of reformism in the Soviet bloc and its implications for a divided Europe. Zdenek Mlynar, one of the architects of the political reforms and in 1968 the youngest member of the Politburo, described the way Leonid Brezhnev and the Soviet leadership spelled out the reasons for the invasion to Dubček and his colleagues:

Precisely because the territorial results of the last war are untouchable to us we had to intervene in Czechoslovakia. The West will not move, so, what do you think will be done on your behalf? Comrades Tito, Ceausescu, Berlinguer, will make speeches. Well, and what of it? You are counting on the Communist movement in Western Europe? But that has remained insignificant for the last fifty years. ${ }^{14}$

That part is familiar enough. Indeed Tito and the "Eurocommunists" in the west protested and claimed to continue the legacy of the Prague Spring as a way to enhance their democratic credentials in western Europe.

The real legacy, however, returned with a vengeance twenty years later. Gorbachev, Mlynar's friend and roommate from their student days in Moscow, became leader of the Soviet Communist Party and sought inspiration for his perestroika in the Prague Spring of 1968. Asked what was the difference was between his reforms and those of Dubček, the spokesman for Gorbachev replied simply: "Nineteen years"... 15

That certainly was not good enough to rehabilitate "socialism with a human face" in the eyes of skeptical Czechs and Slovaks twenty years later. It is not easy to identify with a defeated project with a price tag of another twenty

13. Ibid, $x-x i$.

14. Zdenek Mlynar, Mrazprichazi z Kremlu (Köln, 1979), 306-7. Translated into English as Nightfrost in Prague: The End of Humane Socialism (London, 1980).

15. See the account, for example, in the Washington Post at https://www.washingtonpost.com/archive/politics/1988/08/22/the-birth-of-a-movement/d4fe9126-de3f-499eb2c1-38aaed9951ac/?utm_term=.63efda92dd94 (last accessed October 11, 2018) 
years in a post-totalitarian dictatorship. It did matter, however, for what was unfolding in Moscow and its relationship with its most western dependencies. Jiri Dienstbier, a prominent Czech journalist from 1968 and dissident turned prisoner turned stoker, became Minister of foreign affairs in December 1989. On his first meeting with Gorbachev, he referred to the 1968 hopes crushed by Moscow, to which Gorbachev replied: "We thought that we had strangled the Prague Spring while in reality we had strangled ourselves. .."16

Gorbachev and his entourage saw the Prague Spring as a chance to save the system. Its crushing thus prevented reform at the very center of the empire and accounts for its delayed but intractable crisis. In other words, the August 1968 invasion, by preventing structural change in Czechoslovakia, prepared the ground for the unravelling of "actually existing socialism" (Brezhnev dixit). To be sure, there is tough competition for the title of "who contributed most" to the demise of the Soviet empire. The Hungarians point to the revolution of 1956, the Poles see Solidarity (Solidarność) in 1980, the largest social movement in post-war Europe, which, despite being put down by Wojciech Jaruzelski's military coup, was the swan song of the communist regime. The contribution of the Prague Spring of 1968, even crushed violently, should not be underestimated.

\section{9 as a Continuation or an Anti-1968?}

The "Velvet Revolution" of 1989 was obviously initially planned for 1988, as is appropriate for all major Czechoslovak crises of the twentieth century. Gorbachev's procrastination and other circumstances probably account for the minor delay that put the Velvet Revolution among the fateful eights of the country's history. ${ }^{17}$ It should be noted, however, that although it was obviously understood as the undoing of the legacy of the 1948 communist takeover, it was not framed as a continuation of the "interrupted revolution" of 1968. To be sure, some sidelined 68ers and a number of western observers were inclined to point to that continuity with the aspirations of the Prague Spring, but the main protagonists of 1989 in Prague were eager to distance themselves from the "illusions of 1968." The aim was no longer the democratization of socialism but simply democracy. Instead of searching for a "third way" between capitalism and Soviet-style socialism, the goal was the introduction of markets without adjectives: "the third way leads to the Third World" said Václav Klaus, the promoter of radical free-market economic reforms. Furthermore, the "return to Europe," translated into foreign policy terms, was no longer about extending the margins of maneuvering in central Europe between east and west, but to join western ("Euro-Atlantic") institutions as quickly as possible. Václav Havel rather than Alexander Dubček became president and the embodiment of these goals.

16. J. Dienstbier, quoted in G.E. Castellano and D. Jun, “The Awkward Revolution,” The New Presence (Winter 2008): 17, at http://www.pritomnost.cz/archiv/en/2008/2008_4.pdf (last accessed September 20, 2018).

17. The national independence and formation of the Czechoslovak Republic in 1918, the Munich Agreement of 1938 , the seizing of complete power by the Communist Party in 1948, 1968 and the "Velvet Revolution" of 1988/89. 
The reasons are understandable: it was not easy in 1989 to identify with a project that crashed tragically and was followed by twenty years of relentless "normalization." In dealing with the divide between 68ers and 89ers, it may be useful to distinguish between "illusions" (ideas that you can reform the system from within the Communist Party) and utopias (which entail a futureoriented project known as "socialism with a human face"). All one can add is that 1968 was the last Czech attempt to propose not a blueprint but a vision (deemed utopian or inconsistent afterwards), which transcended the country and concerned Europe as a whole. By way of contrast, 1989 was the first revolution not to propose a new social project; a revolution without violence and utopias, but also without a strong new idea. It was indeed, as historian François Furet called it, a "revolution-restoration" or, as Jürgen Habermas called it, "catch-up revolution" (Nachholende Revolution). ${ }^{18}$ The aim was to restore national and popular sovereignty, the rule of law, private property, and imitate the western model. For that reason, the Velvet Revolution of 1989 has since the 1990s been considered in Prague as an "anti-1968," and today the commemorations concern the tragedy of the invasion of August 1968 rather than the hopes and aspirations of the Spring.

The distancing from the ideas and illusions of 1968 may be understandable. It has, however two snags: if your aim is to imitate western economic and political models, you cease to be interesting for the west. In addition, and more importantly, what if you are imitating a model in crisis? In thinking that one through, you may be forgiven for straying and stumbling upon ideas, projects, and utopias associated with the Prague Spring of 1968.

18. See for example, François Furet, L'Enigme de la désagrégation communiste (Paris, 1990); and Jürgen Habermas, "Nachholende Revolution, Überlegungen und linker Revisionsbedarf: Was heißt Sozialismus heute?" in Die nachholende Revolution: Kleine Plotisiche Schriften VII (Frankfurt-am-Main, 1990): 179-94. 